\title{
IS THERE MORPHOLOGICAL DIFFERENCE BETWEEN BRANCHIOMERIC AND SOMITIC MUSCLES SUBMITTED TO ALCOHOL CONSUMPTION? AN EXPERIMENTAL STUDY IN RATS (RATTUS NORVEGICUS)
}

\author{
EXISTE DIFERENÇA MORFOLÓGICA ENTRE MÚSCULOS BRANQUIOMÉRICOS E \\ SOMÍTICOS SUBMETIDOS AO CONSUMO DE ALCOOL? UM ESTUDO EXPERIMENTAL EM \\ RATOS (RATTUS NORVEGICUS)
}

Jesus Carlos ANDREO', Nícolas Bertolaccini dos SANTOS², Luis Henrique Rapucci MORAES², Matheus Bermejo ANDREO³, Thiago Bermejo ANDREO ${ }^{3}$, Camile Bermejo ANDREO ${ }^{4}$, Antonio de Castro RODRIGUES ${ }^{5}$

\author{
1- DDS, MSc, PhD, Discipline of Anatomy, Department of Biological Sciences, Bauru Dental School, University of São Paulo. \\ 2- Biologist, School of Biological Sciences, Sacred Heart University/USC. \\ 3- Physiotherapist, Physiotherapy School, Sacred Heart University/USC. \\ 4- Veterinary, MD, Veterinary Medicine School/Unimar. \\ 5- DDS, MSc, PhD, Discipline of Anatomy, Department of Biological Sciences, Bauru Dental School, University of São Paulo.
}

Corresponding address: Jesus Carlos Andreo, PhD - Faculdade de Odontologia de Bauru - Departamento de Ciências Biológicas - Disciplina de Anatomia - Al. Octávio Pinheiro Brisolla, 9-75 - Cep.: 17012-901 - Bauru - SP - e-mail: jescandr@fob.usp.br

Received: March 29, 2004 - Modification: September 09, 2004 - Accepted: May 10, 2005

\begin{abstract}
A

lcoholism is considered a physical dependence disorder. More than 18 million people are alcoholics in the USA and England and between $1 / 3$ to $1 / 2$ of them present some kind of physical disorder. In general the literature is focused on alcoholic trunk muscle disorders. These muscles have different embryological origins if compared to the masticatory muscles. The aim of this research was to evaluate the effects of alcohol on the masticatory muscles in order to compare them with the somitic muscles. For this purpose, 15 male Wistar rats weighing around $250 \mathrm{~g}$ were used. The rats were divided into three groups: Normal control (N), Alcoholic (A) and Isocaloric (I). Slices of the masseter muscle, temporalis muscle and rectus abdominal muscle were harvested and submitted to histochemical reactions (m-ATPase: acid and alkaline pre incubation and NADH-TR). The myofibers were classified in SO, FOG and FG. The results showed atrophy of the fast fibers (FG and FOG) in the masticatory muscles but this atrophy was not statistically significant in this study ( $<<0.05)$. On the other hand, significant atrophy occurred in the rectus abdominal muscle $(\mathrm{p}<0.05)$. Based on these data it can concluded that the effect of alcohol on the branchiomeric jaw elevator muscles (masseter and temporalis muscles) is different compared to the effect on somitic muscle (rectus abdominal muscle).
\end{abstract}

Uniterms: Alcoholism; Masseter muscle; Temporalis muscle; Rectus abdominal muscle; Masticatory muscle; Rats.

\footnotetext{
RESUMO

O

alcoolismo é considerado uma doença que causa desordens físicas e também dependência. Mais de 18 milhões de pessoas nos Estados Unidos são alcoólatras e na Inglaterra, entre $1 / 3$ à 1/2 delas apresentam algum tipo de desordem física. No geral a literatura está focada para as desordens que acometem os músculos do tronco. Esses músculos têm origem embriológica diferente dos músculos da mastigação. $\mathrm{O}$ propósito desta pesquisa foi avaliar o efeito do álcool sobre os músculos da mastigação (branquiméricos) no intuito de compará-lo com as alterações que ocorrem nos músculos do tronco (miotômicos). Para isso 15 ratos machos Wistar, pesando ao redor de $250 \mathrm{~g}$ foram utilizados. Os animais foram divididos em três grupos: Controle normal (N); Alcoolizado (A) e Isocalórico (I). Fragmentos dos músculos masseter, temporal e reto do abdome foram coletados e submetidos às reações de m-ATPase (com pré-incubações ácida e alcalina) e NADH-TR. As fibras puderam ser classificadas como FG, FOG e SO. Os resultados mostraram atrofia das fibras de contração rápida (FG e FOG) nos músculos da mastigação, embora esta atrofia, não tenha sido significante entre os grupos estudados. Por outro lado, atrofia significativa foi observada no músculo reto do abdome. Baseado nestes resultados pode-se concluir que o efeito do álcool sobre os músculos elevadores da mandíbula (m. masseter e m. temporal) é diferente se comparado aos observados em músculos somíticos (m. reto abdominal). Unitermos: Alcoolismo; Músculo masseter; Músculo temporal; Músculo reto do abdome; Mastigação; Ratos.
} 


\section{INTRODUCTION}

The World Health Organization (WHO) considers alcoholism a pharmacodependent disease ${ }^{7}$.

There are one to three million alcohol addicts in England and between five to fifteen million in the USA ${ }^{15}$.

Alcohol consumption over a long period is responsible for numerous clinical, biochemical and electrophysiological abnormalities. These alterations are associated with liver, heart, brain and neuromuscular diseases ${ }^{24}$.

Although $30 \%$ to $60 \%$ of chronic alcohol addicts present with alcohol-related myopathologies, this disease is poorly studied.

The consumption of alcohol can produce acute or chronic myofiber alterations. The physiopathological mechanism for this is probably related to the changes in the sarcolemma, ion bomb, a decrease in the contractile power, protein synthesis and genetic problems. In patients with alcoholic myopathy, several organs are frequently affected and reversibility is partially achieved after abstinence ${ }^{5}$.

Clinical and animal studies have demonstrated that the skeletal muscle RNA decreases as a response to ethanol exposure. This reaction contributes to the decrease in protein synthesis. It was also observed that chronic alcoholics present muscle weakness ${ }^{6}$.

Alcohol-related myopathy occurs in $1 / 3$ to $2 / 3$ of alcohol addicts and is characterized by selective fiber type II atrophy, especially type IIB ${ }^{4}$. Otherwise fiber type I is not affected. Thus, up to $20 \%$ of all muscles in the body can be atrophied in this kind of pathology ${ }^{15}$.

In response to abusive alcohol ingestion, other alterations can be observed in the skeletal muscles; the myofiber mosaic pattern is altered; mitochondrial proliferation takes place, intrasarcoplasmatic lipids accumulate ${ }^{20}$.

Myofiber histochemical research has been done in general on the apendicularis muscles. In the masticatory muscles few articles can be found.

The orofacial muscles are very important for humans. The physiological importance of this region is supported by the rich face and mouth sensitive innervation. This area has an extensive somatotopic representation in the sensitive cortex. Thus, the orofacial region is characterized by muscular organization involved in complex movements (masticatory movements) and facial expressions ${ }^{25}$.

Over time, the data obtained on muscle histochemistry of the trunk muscles were extrapolated to the masticatory muscles. Differences in masticatory muscle (i.e. fiber type grouping) were observed in denervated and reinnervated trunk muscles ${ }^{3}$. In the masticatory muscles, the diameter of fiber type II is smaller if compared to fiber type $\mathrm{I}^{17}$. In addition, all myofibers present smaller areas in the masticatory muscles if compared to the trunk muscles ${ }^{17}$. Finally, the mandibular muscles of some species have a proportion of fibers type IIC. This kind of fiber is rare in trunk muscles ${ }^{3}$. Specific differences in the masticatory muscles related to age can be observed. These differences are probably linked to particular, functional activities and hormonal influences
12. The mandibular elevator muscles of the cat present some kind of super fast fibers. These fibers have isometric contraction two times faster than trunk muscle ${ }^{10}$. The mandibular muscles can adapt very fast to the functional demand, changing its composition ${ }^{22}$.

Since no data on the effect of alcohol on masticatory muscles was found in the literature and the histochemical data obtained from the trunk muscles cannot be extrapolated "in toto" to the masticatory muscles, the present study was conducted in order to observe the effects of alcohol on trunk muscles (rectus abdominal muscle) and masticatory muscles (masseter and temporalis muscle).

\section{MATERIALAND METHODS}

Fifteen adult male rats (Rattus norvegicus), weighing between $180 \mathrm{~g}$ and $220 \mathrm{~g}$, were used for this study. At 90 days after birth, the animals were separated and put into individual cages in order to evaluate food and liquid consumption. Weight was evaluated. The lighting schedule in the housing room was 12 hours light and 12 hours dark per day. The temperature of the room was maintained at $21^{\circ} \mathrm{C}$. The animals were divided into three groups, each with 5 animals:

Normal Control (N) - These animals drank normal water.

Isocaloric Group (I) - These animals drank water plus sucrose.

Alcoholic Group (A) - These animals drank 25\% ethyl alcohol diluted with water.

The model of alcoholism used was semi-voluntary. The alcohol and water mix was the only diet offered to the animal.

The alcoholic group was gradually submitted to alcohol during an adaptive period (6\%, 15\% and finally 25\% weekly) after which they were considered alcoholic animals. This protocol was also adopted to avoid their death. Absolute alcohol (MERCK $\mathrm{CH}_{3} \mathrm{CH}_{2} \mathrm{OH}$; PM46.07) was used.

The animals in the isocaloric group (I) received the daily food and liquid mean consumption of the animals in the alcoholic group. For this group the treatment started one day after the alcoholic group, which enabled the researchers to calculate the saccharin diet for the isocaloric group based on the amount of food and liquid consumed in the alcoholic group.

The animals in the normal control group received food and water "ad libitum".

All animals received the same solid diet (Nuvilab CR 1, NUVITAL) during the experimental study.

After the treatment period (120 days), the animals were killed for harvesting of the muscle slices: masseter (superficial portion), temporalis (anterior region) and rectus abdominal muscle. This last muscle was used as a control (the effect of alcohol in trunk muscle is well known).

The animals were killed using an overdose of the anesthetic pentobarbital (Hypnol), via intraperitoneal injection. The procedures were approved by the Institutional Review Board of the Sacred Heart University in Bauru, São Paulo. 
Sections with $10 \mu \mathrm{m}$ thickness, transverse to the longitudinal axis of the fibers were obtained from the harvested slices. After that, the sections were submitted to mATPase (acid and alkaline pre incubation) ${ }^{30}$ and NADHdiaphorase reactions ${ }^{3}$.

Based on these reactions, the myofibers were classified as FG, FOG and $\mathrm{SO}^{13}$.

Reactions obtained from m-ATPase and NADHdiaphorase were represented by using a ZEISS micrometric scale with 10x magnification in an OLYMPUS (model B_MAX 50III) microscope. The pictures were copied using an Olympus printer (model P-330N).

Identification and classification of the myofibers was done using the copies of the slices submitted to the NADHdiaphorase and m-ATPase reactions (alkaline and acid $\mathrm{pH}$ ).

The squares were randomly chosen and 300 fibers were identified. Forty squares were measured for each slice per muscle in each animal.

The square was obtained by using an image analysis system, model Image-Pro Plus version 4.1 linked to a Pentium III computer.

Data were analyzed using analyses of variance (ANOVA) in order to establish whether there was a significant difference between the study groups and the studied muscles. The Tukey test was used where statistically significant differences were found in order to identify these differences.

\section{RESULTS}

The mandibular elevator muscles (masseter and temporalis) presented similar results in all study groups (Table 1).

The mean area and frequency of the myofibers in the masseter muscles, under histochemical criteria, is shown in Tables 2 and 3, respectively.

With regard to the data about the different fiber types found in the masseter muscle, the statistical analysis (ANOVA) did not show any differences between groups. However, for the FG fibers the data showed closer statistically significant difference $(\mathrm{p}<0.05)$.

As regards the data about the frequency of the different fiber types observed in the masseter muscle, the statistical analysis (ANOVA) did not find any differences between groups.

The mean area and frequency of the different fiber types in the temporalis muscles are represented in Tables 4 and 5 respectively.

In the temporalis muscle, the statistical analysis (ANOVA) did not show a significant difference between the FG and FOG areas between groups. On the other hand, the data for the FG fibers are almost significantly different $(\mathrm{p}<0.05)$.

The frequency of the different fiber types observed in the temporalis muscle showed a statistically significant difference in FG and FOG fibers. The Tukey test identified differences between Groups N and A in both FG and FOG fibers.
The histochemical reactions of the myofibers in the rectus abdominal muscle were similar in all study groups. The results are represented in Table 6 .

The area and frequency data of the different fiber types found in the rectus abdominal muscle in all study groups are presented in Tables 7 and 8 respectively.

As regards the data of the areas and different fiber types found in the rectus abdominal muscle, the statistical test (ANOVA) showed a significant difference between the groups only for FG fiber. Otherwise, the numbers of FOG fibers were near the statistically significant difference $(p<0.05)$. The Tukey test showed that the difference found in the area of the FG fibers occurred between $\mathrm{N}$ and $\mathrm{A}, \mathrm{N}$ and I and A and I groups.

With regard to the data about the frequency of the different fiber types found in the rectus abdominal muscle, the statistical analysis (ANOVA) showed significant difference between groups in both FG and FOG fibers. The Tukey test showed that this difference occurred between the $\mathrm{N}$ and I Groups in both FG and FOG fibers.

\section{DISCUSSION}

Several studies about the effects of alcohol on striated muscles can be found in the literature. Some studies were

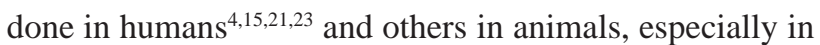
rats $^{14,15,20,27}$ (it has been indicated as a very good experimental model because it presents a selective myofiber type II atrophy, similar to the human).

These studies were done using a day by day alcohol variable dosage. In the human studies, this dosage was between $50 \mathrm{~g}^{19}$ and $240 \mathrm{~g}^{21}$. Other authors claim that this dosage is variable between $100 \mathrm{~g}$ and $400 \mathrm{~g}^{21}$ a day. In rats, this dosage was variable between $36 \%$ consumed calories per day to $48.7 \%$ per day or a $25 \%(\mathrm{w} / \mathrm{v})$ solution ${ }^{27}$. In this study, a $25 \%(\mathrm{w} / \mathrm{v})$ solution was used.

Selective atrophy of fiber type II according to alcohol utilization has been studied in the limbs and trunk muscles $4,6,14,15,20,23,27,28,29$. These data are unknown in the masticatory muscles.

It is very well established that striated muscles respond to functional demand. Thus, the percentage and the area of the different myofibers in the masticatory muscles are variable in animals according to dietary behavior.

For the masseter and temporalis muscles, the literature on fiber types is controversial. This may be because the functional demand changes in relation to the nutritional behavior. It is well known that these muscles have internal compartments that have different tasks. In this study, the slices were always harvested in the same region to avoid errors in accordance with the literature ${ }^{9}$.

The present study found that the anterior portion of the rat temporalis muscle is mainly composed of fast myofibers (FG and FOG). This is in accordance with the other authors, who found less than $1 \%$ of slow myofibers ${ }^{18}$. There are few studies in the literature about the histochemical characteristics of the rat's temporalis myofibers, especially 
in normal and adult rats.

Among the masticatory muscles, the masseter muscle is the most extensively studied. This is probably because it is more superficial. Few papers address normal functional demand ${ }^{18,26}$. The present results corroborated those of other authors that found that the masseter muscle is composed almost exclusively of fast myofibers (FG and FOG).

No papers were found about the effect of alcohol on the temporalis and masseter muscles. They are branchiomeric muscles. Therefore, the present study compared branchiomeric muscles with the myotomic trunk muscle.

In this research, the selective fast myofiber atrophy in the masticatory muscles studied was not significant between groups ( $\mathrm{N}$ and $\mathrm{A}$ or $\mathrm{N}$ and I). On the other hand, in the rectus abdominal muscle, significant fast myofiber atrophy was observed. This result is similar to the myotomic muscles $4,6,14,15,23,27,28,29$.

Some authors ${ }^{1}$ claim that in rats, exercise exacerbates the alcoholic myopathies. If the masticatory process is considered as daily exercise, it could exacerbate the fast myofiber atrophy. This result was not found in the present study.

Some researchers ${ }^{4,15}$ claim that type II fiber atrophy was caused by muscles not being frequently used. In this study the alcoholic rats ate less solid food compared to the other experimental animals, which leads one to think that the less active muscle was responsible for myofiber type II atrophy. However, other studies ${ }^{8}$ concluded that low use is primarily associated with fiber type I atrophy. This was not observed in the present research.

As regards the effect of alcohol on the slow myofiber (Type I), the literature presents conflicting data. Some authors claim that this kind of myofiber is not affected by alcohol consumption ${ }^{4,11,16}$, whereas others claim that fiber type I can develop some weak hypertrophy ${ }^{20}$. Other authors observed atrophy over a long period in myofiber type I but always on a smaller scale than in type $\mathrm{II}^{15}$. In the rectus abdominal muscle a reduction in the area of fiber type SO (I) was observed, although it was not significant between the normal group and the other two groups.

Some authors found that fast myofibers are more affected in the alcohol situation with more significant diameter decrease (fibers type IIB - fast anaerobic glycolytic myofibers) $)^{15,16,21,27}$. These observations are concordant with our observations.

Some data show that the consumption of alcohol can modulate the expression of myosin isoform (MHC) in striated muscles, increasing the MHC expression type I and decreasing the MHC expression of types IIA and IIB ${ }^{21}$. In our research the slow fibers (type I or SO) were found only in the rectus abdominal muscle. In this muscle type I (SO) fibers increased in Group A, although this difference was not significant.

Further studies should be done about the smaller decrease in the fast fibers area in branchiomeric muscles (masseter and temporalis) compared to somitic muscles (rectus abdominal muscle). What is the answer for this phenomenon? There may be different embryologic origins, different innervation, or different functional demand?

\section{CONCLUSION}

The data in the present study indicate that the effect of alcohol on the branchiomeric mandibular elevator muscles (masseter and temporalis) is different if compared to the somitic muscles (rectus abdominal muscle).

\section{ACKNOWLEDGMENT}

The authors thank FAPESP (Proc. N. 2001/02371-9) for the financial support.

\section{REFERENCES}

1- Cook EB, Palmer TN, Peters TJ, Preedy VR. The imposition of moderate exercise on the development of biochemical abnormalities in alcoholic myopathy. Clin Sci. 1994;86(Suppl 30):26.

2- Duane P, Peters TJ. Nutritional status in alcoholocis with and without chronic skeletal muscle myopathy. Alcohol and Alcoholism. 1988;23:271-7.

3- Dubowitz V, Brooke M. Muscle biopsy: a modern approach. London: Saunders; 1973.

4- Fernandez - Sola J, Sacanella E, Estruch R, Nicolas JM, Grau JM, Urbano Marques A. Significance of type II fiber atrophy in chronic alcoholic myopathy. J Neurol Sci. 1995;130(1):69-76.

5- Fernandez - Sola J, Junyent JM, Urbano-Marquez A. Alcoholic myopathies. Curr Opin Neurol. 1996;9(5):400-5.

6- Ferraz ML, Gabbai AA, Oliveira AS, Ferrari AP, Miszputen SJ, Ferreira Neto A, Castelo FilhO A, Schmit B. Histochemical study of the skeletal muscle in chronic alcoholism. Arq Neuropsiquiatr 1989;47(2):139-49.

7- Fortes JRA, Cardo WN. Alcoolismo e distúrbios carenciais In: Alcoolismo: diagnóstico e tratamento. São Paulo: Sanvier; 1991.

8- Gibson JNA, Halliday D, Morrison A. Decrease in human quadriceps muscle protein turnover consequent upon leg immobilization. Clin Sci. 1987;72:503-9.

9- Hiiemae K. The structure and function of the jaw muscle in the rat (Rattus norvegicus L.) I. Their anatomy and internal architecture. Zool F Linn Soc. 1971;50:75-99.

10- Hoh J.F. Myogenic regulation of mammalian skeletal muscle fibres. N Physiol Sci. 1992;6:1-6.

11- Martin F, Ward K. Slavin G, Levi J, Peters TJ. Alcoholic skeletal myopathy a clinical and pathological study. Quart J Med. 1985;55:233-51.

12- Monemi M, Eriksson PO, Eriksson A, Thornell LE. Adverse changes in fire type composition of the human masseter versus biceps brachii muscle during aging. J Neurol Sci. 1998;154(1):35-48.

13- Peter J.B, Barnard RJ, Edgerton VR, Gillespie CA, Stemdel KE. Metabolic profiles of the three fibre types of the skeletal muscle in guinea pigs and rabbits. Biochemistry. 1972;11:2627-33. 
14- Preedy VR, Gove CD, Panos MZ, Sherwood R, Portmann B, Williams R, Peters TJ. Liver histology, blood biochemistry and RNA, DNA and subcellular protein composition of various skeletal muscle of rats with experimental cirrhosis: implications for alcoholic muscle disease. Alcohol Alcohol. 1990;25(6):641-9.

15- Preedy VR, Salisbury JR, Peters TJ. Alcoholic muscle disease: features and mechanisms. J Pathol. 1994;173(4):309-15.

16- Reilly ME, Erylmaz EI, Amir A, Peters TJ, Preedy VR. Skeletal muscle ribonuclease activities in chronically ethanol-treated rats. Alcohol Clin Exp Res. 1998;22(4):876-83.

17- Ringqvist M. Fiber types in human masticatory muscles, relation to function. Scand J Dent Res. 1974;82:333-55.

18- Rokx JM, Van Willigen JD, Jansen HWB. Muscle fibre types and muscle spindles in the jaw musculature of the rat. Arch Oral Biol. 1984; 29(1):25-31.

19- Rubin E, Katz AM, Lieber CS, Stein EP, Puszkin S. Muscle damage produced by chronic alcohol consumptio. Am J Pathol 1976;83:499516

20- Salisbury JR, Preedy VR, Rose PE, Deverell MH, Petters TJ. Ethanol-induce chronic myopathy in the young rat: a light and electron microscopic study in type I or type II fibre-rich skeletal muscles. Alcohol Alcohol. 1992;27(5):493-500

21- Sestoft L, Iversen P, Nordgaard I, Amris S, Joen T, Overgaard O, Klitgaard $\mathrm{H}$. Working capacity and expression of myosin heavy chain isoforms in skeletal muscle of chronic alcoholic men with liver disease after 1 day and 4 wee of alcohol abstinence. Clin Scin Colch. 1994;86(4):433-40.

22- Sfondrini G, Reggiani C, Gandini P, Bovenzi R, Pellegrino MA. Adaptations of masticatory muscles to a hyperpropulsive applicance in the rat. Am J Orthod Dentofacial Orthop. 1996;110(6):612-7.

23- Sharma SC, Ray RC, Banerjee AK, Laskshmanan C. Chronic muscle wasting in alcoholics a histochemical and biochemical study. Indian J Pathol Microbiol. 1990;33(3):244-9.

24- Spencer H. Chronic alcoholism-frequentely overlooked cause of osteoporosis in men. Am J Med. 1986;80:393-7.

25- Stal P. Characterization of the human oro-facial and masticatory muscles with respect to fibre types, myosin and capillaries. Swed Dent J. 1994;98(Suppl):7-45.

26- Suzuki A. A comparative histochemical study of the masseter muscle of the cattle, sheep, swine, dog, guinea pig and rat. Histochemistry. 1977;51:121-31.

27- Trounce I, Byrne E, Dennett X. Biochemical and morphological studies of skeletal muscle in experimental chronic alcoholic myopathy. Acta Neurol Scand. 1990;82(6):386-91.

28- Wassif WS, Preedy VR, Summer B, Duane P, Leigh N, Peters TJ. The relationship between muscle fibre atrophy factor, plasma carnosinase activies and muscle RNA and protein composition in chronic alcoholic myopathy. Alcohol Alcohol. 1993;28(3):325-31.

29- Wassif WS, Sherman D, Salisbury JR, Peters TJ. Use of dynsmic tests of muscle function and histomorphometry of quadriceps muscle biopsies in the investigation of patients with chronic alcohol misuse and chronic fatigue syndrome. Ann Clin Biochem. 1994;31(5):462-

30- Werneck LC. O valor da biopsia muscular em neurologia (Análise de 290 exames a fresco pela histoquímica). Rev Brasil Clin Terap. 1981;10:2-24. 
TABLE 1- Histochemical results of the masseter and temporalis muscles submitted to the myosin ATPase and NADH-Tr staining in the Normal, Alcoholic and Isocaloric groups

\begin{tabular}{lclll}
\hline & $\begin{array}{l}\text { m ATPase } \\
\text { (pH 10.3) } \\
\text { Fig. 01 }\end{array}$ & $\begin{array}{l}\text { m ATPase } \\
\text { (pH 4.65) } \\
\text { Fig. 02 }\end{array}$ & $\begin{array}{l}\text { m ATPase } \\
\text { (pH 4.5) }\end{array}$ & $\begin{array}{l}\text { NADH-Tr } \\
\text { Fig. 04 }\end{array}$ \\
\hline 1- FG fiber & + & + & Fig. 03 & + \\
2- FOG fiber & ++ & ++ & + & ++ \\
\hline
\end{tabular}

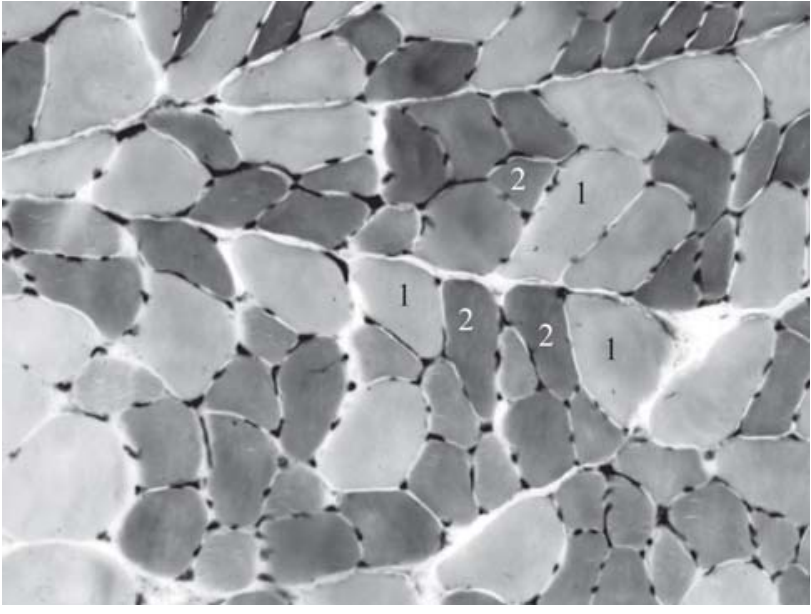

FIGURE 1- Histochemical alkaline myosin ATPase (pH 10.3) staining of masseter and temporalis muscles. 1= FG fiber; 2= FOG fiber

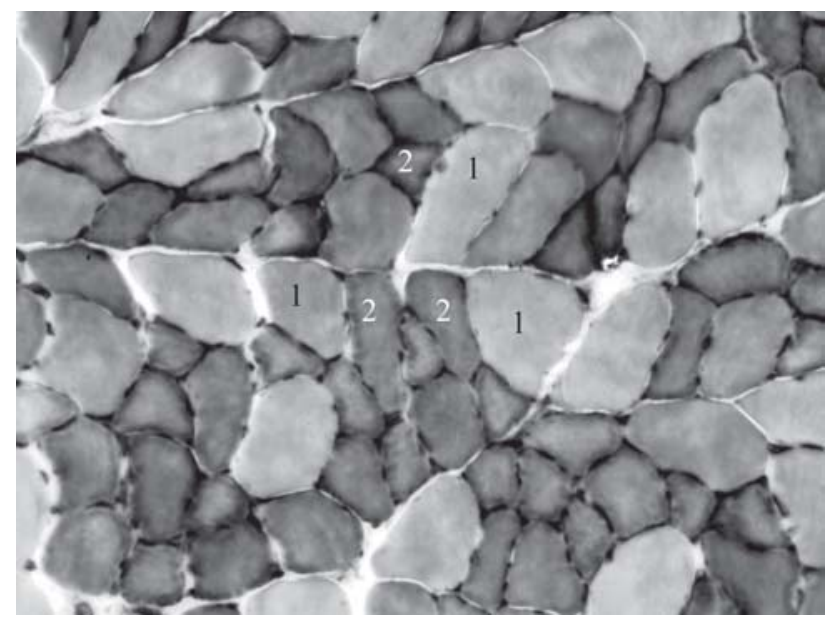

FIGURE 3- Histochemical acid myosin ATPase ( $\mathrm{pH} 4.45)$ staining of masseter and temporalis muscles. 1= FG fiber; 2= FOG fiber

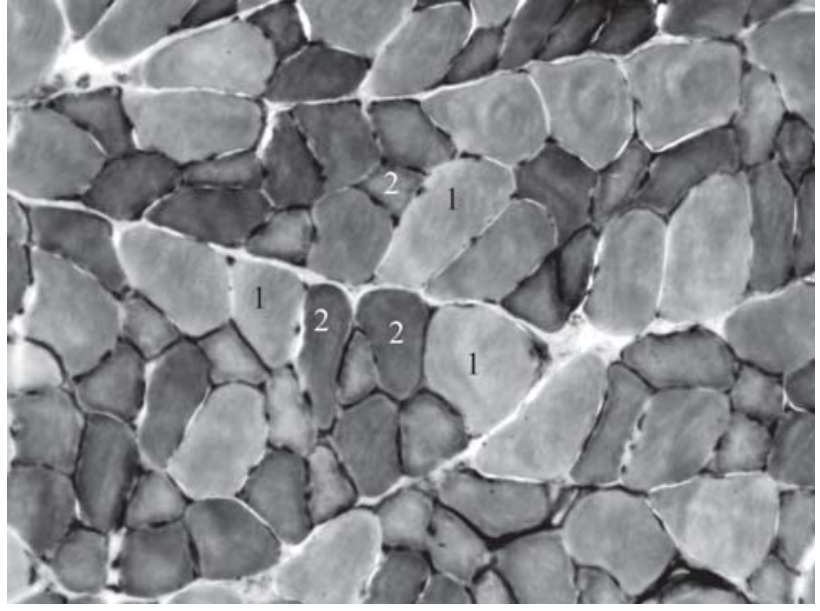

FIGURE 2- Histochemical acid myosin ATPase ( $\mathrm{pH} \mathrm{4.65)}$ staining of masseter and temporalis muscles. 1= FG fiber; 2= FOG fiber

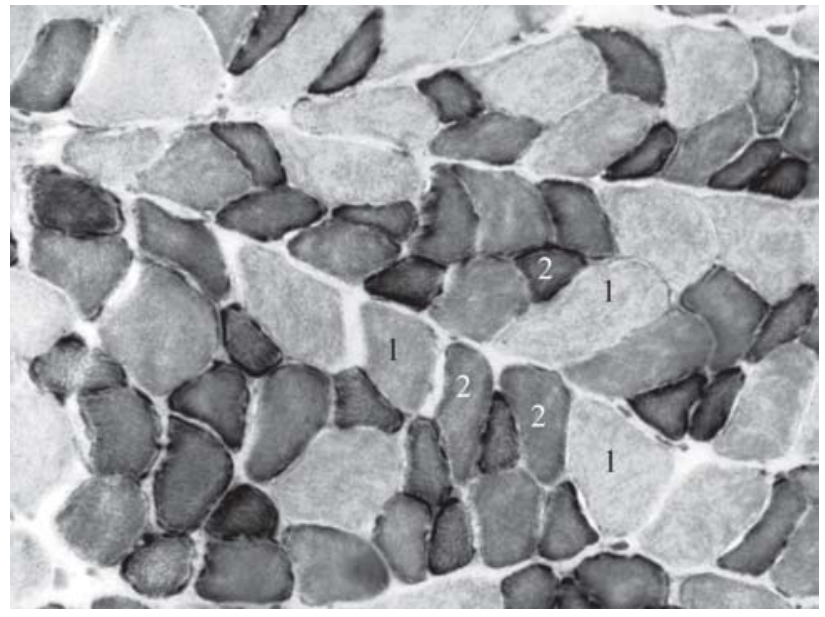

FIGURE 4- Histochemical NADH-Tr staining of the masseter and temporalis muscles. 1= FG fiber; 2= FOG fiber 
TABLE 2- Mean area $\left(\mathrm{um}^{2}\right)$ of the different fiber types in the masseter muscle in the animals of the Normal, Alcoholic and Isocaloric groups

\begin{tabular}{|c|c|c|c|c|c|c|c|c|}
\hline \multirow[t]{2}{*}{ Fibers } & \multicolumn{2}{|c|}{ Normal } & \multicolumn{2}{|c|}{ Alcoholic } & \multicolumn{2}{|c|}{ Isocaloric } & \multirow[b]{2}{*}{$\mathbf{F}$} & \multirow[b]{2}{*}{$\mathbf{P}$} \\
\hline & $x$ & SD & $x$ & SD & $x$ & SD & & \\
\hline $\mathrm{FG}$ & 3.18 & 0.47 & 2.47 & 0.51 & 2.49 & 0.52 & 3.26 & 0.0073 \\
\hline FOG & 2.05 & 0.24 & 1.59 & 0.35 & 1.61 & 0.47 & 2.42 & 0.130 \\
\hline
\end{tabular}

TABLE 3- Frequency (\%) of the different fiber types in the masseter muscle in the animals of the Normal, Alcoholic and Isocaloric groups

\begin{tabular}{|c|c|c|c|c|c|c|c|c|}
\hline \multirow[t]{2}{*}{ Fibers } & \multicolumn{2}{|c|}{ Normal } & \multicolumn{2}{|c|}{ Alcoholic } & \multicolumn{2}{|c|}{ Isocaloric } & \multirow[b]{2}{*}{$F$} & \multirow[b]{2}{*}{$\mathbf{P}$} \\
\hline & $x$ & SD & $x$ & SD & $x$ & SD & & \\
\hline FG & 50.9 & 8 & 55.5 & 8 & 58.7 & 7 & 1.38 & 0.288 \\
\hline FOG & 49.1 & 8 & 44.5 & 8 & 41.3 & 7 & 1.38 & 0.288 \\
\hline
\end{tabular}

TABLE 4- Mean area $\left(\mathrm{um}^{2}\right)$ of the different fiber types in the temporalis muscle in the Normal, Alcoholic and Isocaloric groups

\begin{tabular}{|c|c|c|c|c|c|c|c|c|}
\hline \multirow[t]{2}{*}{ Fibers } & \multicolumn{2}{|c|}{ Normal } & \multicolumn{2}{|c|}{ Alcoholic } & \multicolumn{2}{|c|}{ Isocaloric } & \multirow[b]{2}{*}{$F$} & \multirow[b]{2}{*}{$\mathbf{P}$} \\
\hline & $x$ & SD & $x$ & SD & $x$ & SD & & \\
\hline FG & 4.40 & 1.57 & 2.64 & 0.67 & 3.60 & 0.44 & 3.73 & 0.054 \\
\hline FOG & 2.16 & 0.81 & 1.58 & 0.86 & 1.70 & 0.28 & 0.96 & 0.407 \\
\hline
\end{tabular}

TABLE 5- Frequency (\%) of the different fiber types in the temporalis muscle in the animals of the Normal, Alcoholic and Isocaloric groups

\begin{tabular}{|c|c|c|c|c|c|c|c|c|}
\hline \multirow[t]{2}{*}{ Fibers } & \multicolumn{2}{|c|}{ Normal } & \multicolumn{2}{|c|}{ Alcoholic } & \multicolumn{2}{|c|}{ Isocaloric } & \multirow[b]{2}{*}{$\mathbf{F}$} & \multirow[b]{2}{*}{$\mathbf{P}$} \\
\hline & $x$ & SD & $x$ & SD & $x$ & SD & & \\
\hline FG & $65.1^{a}$ & 7 & $79.2^{\mathrm{b}}$ & 4 & $73.5^{a b}$ & 6 & 6.84 & $0.010^{*}$ \\
\hline FOG & $34.9^{a}$ & 7 & $20.8^{b}$ & 4 & $26.5^{\mathrm{ab}}$ & 6 & 7.01 & $0.009^{*}$ \\
\hline
\end{tabular}

Groups with the same letter do not present statistically significant difference among them. 
TABLE 6- Histochemical results of the rectus abdominal muscle submitted to the myosin ATPase and NADH-Tr staining in the Normal, Alcoholic and Isocaloric groups

$\begin{array}{lccc}\text { m ATPase } & \text { m ATPase } & \text { m ATPase } & \\ (\mathrm{pH} \mathrm{10.6)} & (\mathrm{pH} \mathrm{4.6)} & (\mathrm{pH} \mathrm{4.45)} & \text { NADH-Tr } \\ \text { Fig. 05 } & \text { Fig. 06 } & \text { Fig. 07 } & \text { Fig. 08 }\end{array}$

\begin{tabular}{lllll}
\hline 1- SO fiber & + & +++ & ++++ & +++ \\
2- FOG fiber & +++ & ++ & ++ & ++ \\
3- FG fiber & ++ & + & + \\
\hline
\end{tabular}

+ weak reactive ++ intermediate reactive $\quad+++$ strong reactive

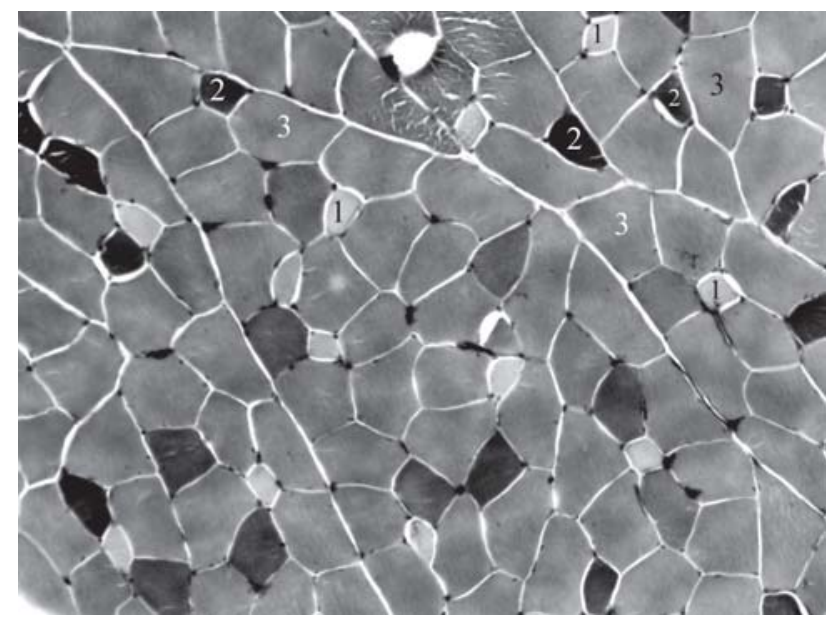

FIGURE 5- Histochemical alkaline myosin ATPase (pH 10.6) staining of rectus abdominal muscle. $1=$ SO fiber; $2=$ FOG fiber; 3= FG fiber

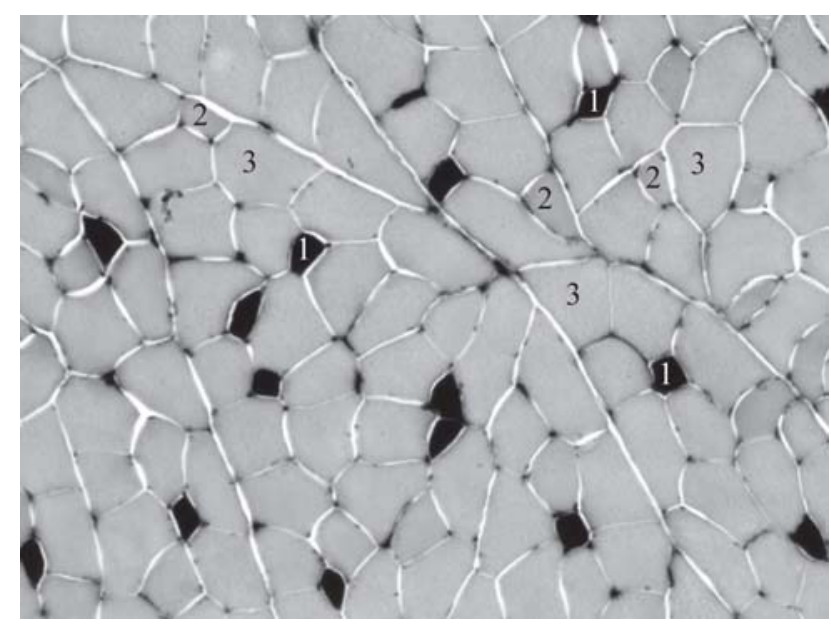

FIGURE 7- Histochemical acid myosin ATPase ( $\mathrm{pH} 4.45)$ staining of rectus abdominal muscle. $1=\mathrm{SO}$ fiber; $2=\mathrm{FOG}$ fiber; 3= FG fiber

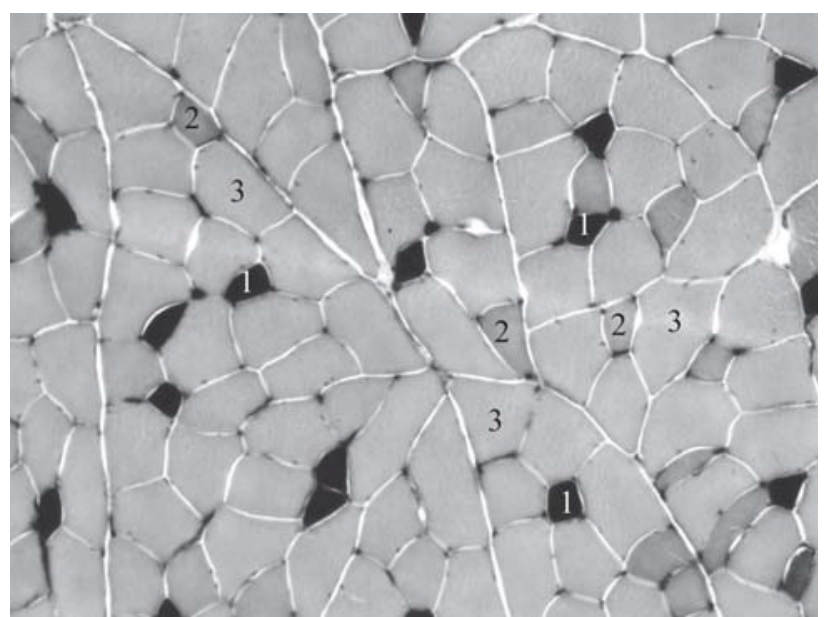

FIGURE 6- Histochemical acid myosin ATPase $(\mathrm{pH} 4.6)$ staining of rectus abdominal muscle. $1=$ SO fiber; $2=$ FOG fiber; 3= FG fiber

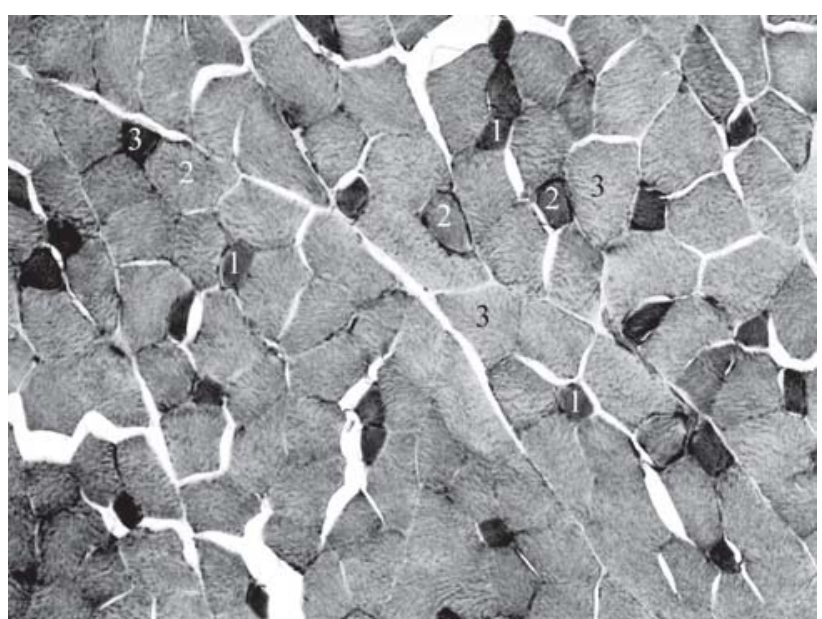

FIGURE 8- Histochemical NADH-Tr staining of rectus abdominal muscle. 1= SO fiber; $2=$ FOG fiber; $3=$ FG fiber 
TABLE 7- Mean area $\left(u^{2}{ }^{2}\right)$ of the different fiber types in the rectus abdominal muscle in the Normal, Alcoholic and Isocaloric groups

\begin{tabular}{|c|c|c|c|c|c|c|c|c|}
\hline \multirow[t]{2}{*}{ Fibers } & \multicolumn{2}{|c|}{ Normal } & \multicolumn{2}{|c|}{ Alcoholic } & \multicolumn{2}{|c|}{ Isocaloric } & \multirow[b]{2}{*}{$F$} & \multirow[b]{2}{*}{$\mathbf{P}$} \\
\hline & $x$ & SD & $x$ & SD & $x$ & SD & & \\
\hline FG & $6.43^{a}$ & 0.91 & $3.31^{b}$ & 0.91 & $4.77^{c}$ & 0.38 & 20.40 & $0.000^{*}$ \\
\hline FOG & 2.72 & 0.82 & 1.87 & 0.46 & 1.90 & 0.19 & 3.78 & 0.053 \\
\hline so & 0.93 & 0.14 & 0.69 & 0.15 & 0.83 & 0.32 & 1.60 & 0.241 \\
\hline
\end{tabular}

No statistical significant difference for the same letter numbers.

TABLE 8- Frequency (\%) of the different fiber types in the rectus abdominal muscle in the animals of the Normal, Alcoholic and Isocaloric groups

\begin{tabular}{|c|c|c|c|c|c|c|c|c|}
\hline \multirow[t]{2}{*}{ Fibers } & \multicolumn{2}{|c|}{ Normal } & \multicolumn{2}{|c|}{ Alcoholic } & \multicolumn{2}{|c|}{ Isocaloric } & \multirow[b]{2}{*}{$F$} & \multirow[b]{2}{*}{$\mathbf{P}$} \\
\hline & $x$ & SD & $\mathrm{X}$ & SD & $x$ & SD & & \\
\hline FG & $63.6^{a}$ & 1.84 & $60.9^{a b}$ & 4.09 & $57.7^{b}$ & 5.59 & 4.04 & $0.045^{\star}$ \\
\hline FOG & $22.3^{a}$ & 3.84 & $23.7^{\mathrm{ab}}$ & 2.18 & $28.3^{b}$ & 5.16 & 4.08 & 0.0448 \\
\hline so & 14.1 & 2.98 & 15.4 & 3.80 & 14.1 & 5.93 & 0.13 & 0.873 \\
\hline
\end{tabular}

No statistical significance difference for numbers with same letter. 